|Araştırma Makalesi / Research Article |

\title{
Argümantasyon Uygulamalarının 5. Sınıf Öğrencilerinin Madde ve Değişim Ünitesi Başarılarına ve Bireysel Değişimlerine Yansıması
}

\section{Reflection of Argumentation Practices on Matter and Exchange Unit Achievements and Individual Change of 5th Grade Students}

\section{Büşra Nur Çakan Akkaş ${ }^{1}$, Esra Kabataş Memiş ${ }^{2}$}

\author{
Anahtar Kelimeler \\ araştırma-sorgulama \\ argümantasyon \\ madde ve değişim \\ ünite başarısı
}

\section{Keywords \\ research-inquiry \\ argumentation \\ matter and exchange \\ unit succes}

Başvuru Tarihi/Received
04.11.2019

Kabul Tarihi /Accepted

16.03.2020

\section{Öz}

Çalışmada argümantasyon uygulamalarının ortaokul 5. sınıf öğrencilerinin "Madde ve Değişim" ünitesi başarılarına etkisi ve bu süreç sonunda öğrencide meydana gelen değişimler incelenmiştir. Araştırmanın modelini deneysel araştırma modellerinden ön test - son test kontrol gruplu yarı deneysel desen oluşturmaktadır. Çalışma 2016-2017 eğitim-öğretim yılında Türkiye'nin Kuzeybatısında bulunan bir ortaokulun iki farklı beşinci sını öğrencileri ile gerçekleştirilmiştir. Sınıflar-dan biri deney grubu diğeri ise kontrol grubu olarak çalışma öncesinde rastgele belirlenmiştir. Kontrol grubunda Fen Bilimleri dersleri düz anlatım, soru cevap, gösteri deneyleri gibi sıkıkla kullanılan öğretim yöntemleriyle gerçekleştirilmiştir. Deney grubunda ise dersler araştırma-sorgulamayı temel alan argümantasyon etkinlikleri ile yürütülmüştür. Uygulama, toplamda beş hafta sürmüştür. Araştırmada veri toplama aracı olarak çoktan seçmeli ve açık uçlu sorulardan oluşan ünite tabanlı başarı testi ve yarı yapılandırılmış görüşme soruları kullanılmıştır. Uygulamaların tamamlanmasının ardından öğrencilere başarı testi uygulanmış, deney ve kontrol gruplarından altışar olmak üzere toplam 12 öğrenci ile görüşmeler gerçekleştirilmiştir. Elde edilen nicel verilere ilişkisiz örneklemler $\mathrm{t}$-testi ve tek faktörlü ANCOVA analizleri uygulanırken nitel veriler tematik analiz ile değerlendirilmiş-tir. Sonuç olarak testte yer alan çoktan seçmeli, açık uçlu sorular ve test toplam puanlarını argümantasyon etkinliklerine katılan deney grubu öğrencileri lehine anlamlı bir şekilde farklılaştığı belirlenmiștir. Ayrıca deney grubundaki öğrenciler süreç sonunda daha iyi öğrendiklerini, öğrendikleri bilgilerin kalıcı olduğunu, fen bilimleri dersini sevdiklerini ve öz güvenlerinin arttığını belirtmişlerdir.

\section{Abstract}

In this study were examined the effect of argumentation applications on the "Matter and Exchange" unit achievement of secondary school fifth grade students and the changes occurred in the student at the end of this process. The re-search model consists of a quasi-experimental design with pre-test and post-test with control groups. The study was conducted with two different fifth grade students of a second-ary school in the 2016-2017 academic year. One of the classes was determined randomly before the study as the experi-mental group and the other as the control group. In the con-trol group, science lessons were carried out by using with frequently methods such as direct instruction, question-answer and display experiments. In the experiment group, lessons were conducted based on with research and inquiry argumentation activities. The application lasted total of five weeks. As data collection tool in the study, unit-based achievement test consisting of multiple choice and open ended questions and semi-structured interview questions were used. Success test were applied to the students after the completion of the applications, interviews were conducted with a total of 12 students, six from the experimental and control groups. The quantitative data were analyzed by using independent samples t-test and one way ANCOVA analysis while qualitative data were evaluated by thematic analysis. As a result, it was determined that differ significantly in favor of the experimental group students participating in the argumentation activities the multiple choice, open-ended questions and test total scores in the test. In addition, the students in the exper-imental group stated learned better at the end of the process that the information they learned was permanent, they liked science lesson and their self-confidence increased.

\footnotetext{
${ }^{1}$ Kastamonu Üniversitesi, Fen Bilimleri Enstitüsü, Kastamonu, Türkiye; https://orcid.org/0000-0001-9628-069X

${ }^{2}$ Kastamonu Üniversitesi, Eğitim Fakültesi, Matematik ve Fen Bilimleri Eğitimi Bölümü, Kastamonu, Türkiye; https://orcid.org/0000-0003-0946-2626
} 


\section{Extended Abstract}

\section{Introduction}

It is important for individuals to be skeptical about the accuracy and reliability of the information they encounter in both their education and daily life, to investigation this information instead of directly accepting it and to structure it in relation to its previous knowledge. Instead of a teacher-centered education, it is one of the aims of science education to educate individuals researcher, learn the ways of obtaining information, creative, develops the ability to analyze and synthesize, demonstrate the ability to use what they learn in social and private life (Bozkurt, 2012). It is possible for individuals to gain the specified behaviors by experiencing these behaviors in learning environments. It can be said that argumentation based on research and inquiry provides students with the opportunity to use these behaviors. According to Keselman (2003), in inquiry-based learning, students structure information follow processes similar to the methods and practices of scientists. The argumentation process provides the opportunity to create a learning environment that includes many dimensions such as pre-learning, high-level questions, intensive thinking, conducting laboratory activities, discussions using evidence. Argumentation in science classes can be used to development of concep-tual understanding and research ability, to understand science as a social practice (Driver, Newton \& Osborne, 2000). In view of the above, it is possible to say that argumentation practices provide students with a multidimensional development. In this direction, the aim of this study is examine to the effect of argumentation on the success of the fifth grade students and the changes in the students at the end of this process. Within the scope of the aim, our research is in the form of problems; "Does the fifth grade students' argumentation practices in science courses have an effect on the achievement of the "Matter and Exchange" unit?" and "What are the changes in students at the end of the process?"

\section{Method}

The research model consists of a quasi-experimental design pre-test and post-test with control groups. The fall semester of 2016-2017 academic year, in the northwest of Turkey, fifth-grade students from two different branches located at a secondary school represents the study groups. One of the classes was determined randomly before the study as the experimental group (39 students) and the other as the control group (39 students). In the control group, science lessons were carried out by using with frequently methods such as direct instruction, question-answer and display experiments. In the experiment group, lessons were conducted based on with research and inquiry argumentation activities. The experimental group students completed their argumentation activities in 7 small groups consisting of 5-6 people each. As data collection tool in the study, unit-based achievement test and semi-structured interview questions were used. A success test consisting of 20 multiple choice questions and 5 open ended questions was prepared within the scope of the "Matter and Exchange" unit. Expert opinions regarding test and interview ques-tions were received and the data collection tools were finalized with the necessary arrangements. The achievement test was applied to experimental and control groups as pre-test and post-test. With the completion of the applications, semi-structured interviews were conducted with a total of 12 students, six of whom were experimental and control groups. The data obtained from the achievement test were applied "descriptive statistics", "independent samples t-test" and "one way ANCOVA" analysis. Thematic analysis was applied to the data obtained through interviews.

\section{Result and Discussion}

Unit-based achievement test and semi-structured interview questions were used in the study. The open-ended and multiplechoice questions in the achievement test were analyzed separately. When the pre-test data were analyzed, it was found that the experimental and control groups did not differ statistically significantly in terms of multiple choice $(t(78)=-0.932, p=0.354)$, openended $(t(78)=0.678, p=0.500)$ and test total scores $(t(78)=-0.112, p=0.911)$. When the findings of the post-test data were examined, it was found that there were statistically significant differences between the in addition to total score $(F(1,78)=44.454$, $\left.p=0.000, \eta_{p}^{2}=0.399\right)$ of the test and the scores of multiple choice $\left(F(1,78)=8.204, p=0.005, \eta_{p}{ }^{2}=0.097\right)$ and open-ended questions $\left(F(1,78)=43.651, p=0.00, \eta_{p}{ }^{2}=0.394\right)$ in favor of the experimental group. Thematic analysis was applied to the qualitative data obtained from the interviews. Because of the analysis, experimental group students stated that they learned better thanks to their argumentation practices, that the information they learned was permanent, that they could easily focus on the lesson and that they liked science lesson. Control group students learned through repetitions and question solutions and that their knowledge was permanent, and that they had difficulty in focusing on the course during this learning process. As a result, it is possible to say that the argumentation applications carried out with the experimental group increased the students' achievement of "Matter and Exchange" unit more than the control group and this process contributes to the multi-faceted development of students based on student statements. While the students in the control group listened to the information transmitted by the teacher like a listener, the experimental group students questioned and discussed the information with their peers. In this way, the experimental group students had a continuous thinking activity and actively structured the information. It is thought that the success of the experimental group students in the unit test is related to the above-mentioned situations. 


\section{GíRiş}

Son yıllarda dünya genelinde fen eğitimi üzerine yapılan birçok çalışmada araştırma-sorgulama sıklıkla vurgulanmaktadır. "Araştıran-sorgulayan bireyler yetiştirmek" ifadesi de yapılan yenilikler ile fen öğretim programlarına dâhil edilmiştir. Fen Bilimlerine ilişkin temel kavramların kazandırılması, öğrencinin kendi öğrenmesinden sorumlu olması ve bu sürece aktif katılımının sağlanması, araştırma-sorgulama ve bilginin transferine dayalı öğrenme strateji-sinin benimsenmesi hem 2013 hem de 2018 Fen Bilimleri Öğretim Programlarının temel noktalarıdır (MEB, 2013; MEB, 2018). Fen eğitiminin amacı; öğretmen merkezli öğretimin yerine araştırmacı, bilgiyi edinme yollarını öğrenen, yaratıcı, analiz ve sentez yeteneğini geliştiren, öğrendiklerini sosyal ve özel yaşamında kullanabilme becerisi gösteren bireyler yetiştirmektir (Bozkurt, 2012). Bu noktadan hareketle fen eğitiminin temel amaçları içerisinde öğrencilerin öğrenme sürecine dâhil edilmesi ve bu öğrenme sürecinde araştırma-sorgulama faaliyetlerinin yürütülmesi ön plana çıkmaktadır. Ayrıca öğrencilerin araştırma-sorgulamayı benimseyerek sosyal yaşamlarında da aktif bir şekilde kullanmaları vurgulanan önemli bir noktadır.

Fen eğitiminde araştırma-sorgulamaya dayalı etkinlikler sayesinde öğrenciler öğrenme sürecine dâhil edilir ve öğrenciler bir bilim insanı gibi yeni bilgileri keşfetme imkanı bulurlar (Hand, 2008). Araştırma-sorgulama; öğrencileri, bir konu veya bir kavramı çevreleyen soruları ve soruların cevaplarını keşfetmeye aktif olarak dâhil eden bir öğrenme süreci oluşturur (Jill, 2007). Araştırmasorgulamanın fen eğitimindeki temel amacı, doğru ön bilgiler ve etkili öğrenme ortamları sağlayarak bireylerin bilgileri özümseyerek yapılandırmalarını sağlamaktır (Kabataş Memiş ve Çakan Akkaş, 2016). Walker ve Sampson (2013)'a göre araştırmasorgulamaya dayalı öğrenme; bir araştırma sorusunu desteklemek amacıyla laboratuvar faaliyetleri yürütmek, bu faaliyetler sonucunda argümanlar geliştirmek ve argümanlarla araştırma problemini açıklama çabası şeklinde özetlemektedir. Bu faaliyetlerin yanı sıra araştırma-sorgulama; kanıtlarla birlikte fikirlerin tartışıldığı, üst düzey soruların sorulduğu, yoğun bir şekilde düşünmenin gerçekleştirildiği bir yapıya sahiptir.

Araştırma-sorgulamayı temel alan argümantasyon, mutlak bir doğruya ulaşma çabasından çok, bir duruma ilişkin öne sürülen iddiaların, elde edilen veriler ışığında delillerle birlikte desteklenmesi veya karşı çıkılması, olaylar ve fikirler arasındaki mantıksal ilişkinin belirlenme sürecidir (Duschl \& Osborne, 2002). Argümantasyonun düşüncelerin test edilmesi için bir araç olduğunu belirten Toulmin (1958) argümantasyonu, iddialar ve veriler arasındaki ilişkiyi gerekçeler ile yapılandırma süreci olarak ifade etmiştir. Birbirinden farklı düşüncelerin ve fikirlerin bulunduğu bir ortamda bu düşünceler içerisinde en kabul edilebilir olanı tercih etmede argümantasyon etkili bir şekilde kullanılır. Bu nedenle argümantasyon süreci boyunca öne sürülen bir iddianın desteklenmesi için toplanan kanıtların iddia ile nasıl ilişkilendirildikleri ve iddiayı kanıtlamada nasıl kullanıldıkları önemli bir noktadır. Kuhn (2009) argümantasyonun karşıt görüşlerden kişinin kendi iddiasını destekleyen kanıtları kullanması ve karşı iddiaların zayıflıklarının tespit edilerek çürütülmesi olmak üzere iki önemli hedefini vurgular. Bu süreçte bir iddiayı destekleyen kanıtların sayısı ne kadar fazla ve kanıtların iddialar ile ilişkisi ne kadar güçlü ise argümanın kalitesi de o oranda artar. Argümantasyon sürecinde olduğu gibi fen eğitiminde kanıt kullanmak iki önemli amaca hizmet etmektedir. Birincisi; bir iddiayı eleştirerek (destekleme veya çürütme) yeni bilgilerin yapılandırılmasını ve ikincisi; öğrencilerin bilimi, gerçeklerin ezberlenmesinden çok bilimsel bilgilerin oluşturulduğu bir süreç olarak görmelerini sağlamasıdır (Banilower, Cohen, Pasley \& Weiss, 2010). Böylece öğrencilerin zihinlerinde bilimsel bilgileri yapılandırmanın yanı sıra bilime ilişkin daha doğru bir algıya sahip olmaları sağlanabilir.

Argümantasyon sürecinin en önemli bileşenlerinden biri de tartışma basamağıdır. Bilimde, bilimsel bilgilerin geçerliliği için tartışma etkinlikleri ne kadar önemli ise fen derslerinde de bilgilerin yapılandırılmasında tartışma faaliyetleri o kadar önemlidir (Kuhn, 2009). Bu nedenle öğretmenlerin fen derslerinde tartışmaya imkân sağlayacak ortamlar oluşturması gerekmektedir. Öğretmenin bu ortamları oluşturmada en önemli görevi tartışmayı başlatan ve tartışmayı sürdüren etkili sorular sorarak rehber olmasıdır. Osborne, Erduran, Simon ve Monk (2001) öğretmenin, belirlenen bir dizi sorular arasından uygun olanı seçerek tartışma sürecini başlatabileceğini veya sürdürebileceğini vurgulamışlardır. Araştırmacılar tarafından belirtilen sorular:

-Neden böyle düşünüyorsun?

-Bunun sebebi sence nedir?

-Görüşün için başka argüman düşünebilir misin?

-Görüşüne karşı bir argüman düşünebilir misin?

-Nasıl biliyorsun?

-Kanıtın nedir?

-Düşüncen için başka bir argümanın var mı? şeklindedir.

Yukarıda belirtilenlerden hareketle araştırma sorgulamayı temel alan argümantasyon; ön öğrenmeler, üst düzey sorular, yoğun düşünme, laboratuvar etkinlikleri yürütme, kanıtların kullanıldığı tartışmalar gibi birçok boyutu içerisinde barındıran bir öğrenme ortamı oluşturma imkânı sunmaktadır. Bu aktivitelere imkân sağlayan öğrenme ortamlarında öğrenciler, öğrenme sürecine aktif katılarak bilgileri yapılandırma imkânı bulurlar (Akkuş, Günel \& Hand, 2007; Driver, Newton \& Osborne, 2000; Günel, Kabataş Memiş \& Büyükkasap, 2010). Yapmış olduğumuz çalışmada da belirtilen şekilde bir öğrenme ortamı oluşturan argümantasyonun beşinci sınıf öğrencilerinin "Madde ve Değişim” ünitesi başarılarına etkisi ve süreç sonunda öğrencilerde meydana gelen değişimlerin incelenmesi amaçlanmıştır. Bu çerçevede araştırmanın problem durumları "5. sınıf öğrencilerinin Fen Bilimleri derslerinde gerçekleştirilen argümantasyon uygulamalarının “Madde ve Değişimi” ünitesine ilişkin başarılarına etkisi var mıdır?” 
ve "Süreç sonunda öğrencilerin öğrenme, fen bilimleri dersine ilişkin bakış açılarında ve bireysel becerilerinde meydana gelen değişimler nasıldır?" şeklinde ifade edilmektedir.

\section{YÖNTEM}

\section{Araştırma Modeli}

Araştırmanın modelini deneysel araştırma modellerinden ön test-son test kontrol gruplu yarı deneysel desen oluşturmaktadır. Rastgele atama dışında önceden belirlenmiş grupların deney ve kontrol grubu olarak seçildiği, her iki gruba uygulama öncesinde ön test uygulandığı, istenilen çalışmaların deney grubu ile gerçekleştirilirken kontrol grubuna herhangi bir müdahalenin olmadığı ve ardından deney ve kontrol gruplarına son test uygulandığı çalışmalar yarı deneysel yöntemdir (Çepni, 2012).

\section{Çalışma Grubu}

2016-2017 eğitim öğretim yılının güz döneminde, Türkiye'nin kuzeybatısında, bir ortaokulda yer alan iki farklı 5. sınıf öğrencileri çalışma grubunu temsil etmektedir. Çalışma grubunun kolay ulaşılabilir olması ön plandadır. Hali hazırda mevcut olan ve çalışmaya katılması kolay olan bir katılımcı grubunu temsil eder (Chiristensen, Johnson, Turner, 2015). Sınıflardan biri deney grubu, diğeri ise kontrol grubu olarak çalışma öncesinde rastgele seçilmiştir. Deney grubunda 39 öğrenci (21 kız, 18 erkek) ve kontrol grubunda 39 öğrenci (22 kız, 17 erkek) olarak toplam 78 öğrenci çalışmaya katılmıştır.

\section{Uygulama}

Uygulama öncesinde deney ve kontrol grupları Fen Bilimleri derslerini düz anlatım, soru cevap ve gösteri deneylerinin gerçekleştirildiği bir öğrenme ortamında işlemektedirler. Ders esnasında öğretmenin gerekli gördüğü anlarda akıllı tahta kullanılarak görsel öğeler paylaşılmakta ve Fen Bilimleri ders kitabında (Fen Bilimleri Ders Kitabı, 2016-2017) yer alan ünite değerlendirme sorularıyla konular tekrar edilmektedir. Çalışma kapsamında bu öğrenme ortamı geleneksel yaklaşım olarak tanımlanmıştır. Uygulama öncesinde kontrol ve deney gruplarına ünite tabanlı başarı testi uygulanmıştır. Uygulamaların başlamasıyla birlikte kontrol grubu dersleri geleneksel yaklaşıma uygun işlenmeye devam ederken deney grubu dersleri argümantasyon uygulamaları ile yürütülmüştür. Uygulamanın ilk haftasında deney grubu öğrencilerinin argümantasyonun temelini oluşturan iddia ve kanıt hakkında bilgi sahibi olmaları için bir hazırık aktivitesi gerçekleştirilmiştir. Hazırlık aktivitesinde öğrencilerden 5-6 kişilik gruplarında dikkat çekici ve sebebi belli olmayan bir "gizemli ölümü" çözmeleri istenmiştir. Bunun için öğrenciler grupça bir iddia öne sürmüşler ve bu iddialarını metinden elde ettikleri kanıtlarla birlikte desteklemişlerdir. Ardından iddia ve kanıtlarını bir olay örgüsü içerisinde arkadaşları ile paylaşmışlar ve öğrenciler birbirlerini ikna etme süreci yaşamışlardır. Ardından öğrencilerle birlikte iddia ve kanıtın özellikleri üzerine tartışımış ve iddia ile kanıt özellikleri tahtaya yazılmıştır. Devamında öğrencilerle argümantsayonun temelinde yer alan soru sormanın incelikleri üzerine ve nasıl iyi soru sorulabileceği üzerine konuşulmuştur. Hazırık aktivitesinden sonra “Madde ve Değişim” ünitesi kapsamında 4 haftalık araştırma-sorgulama uygulamalarına dâhil olmuşlardır. Hazırlık aktivitesiyle birlikte toplam 5 haftalık uygulama boyunca öğretmen öncelikle büyük grup tartışmaları gerçekleştirerek öğrencilerin konulara ilişkin ön öğrenmelerini açığa çıkarmıştır. Ardından öğrenciler, küçük gruplarında tartışmalar yürüterek deneyler tasarlamış ve uygulamışlardır. Öğretmen ise küçük grupları teker teker dolaşarak sürece uygun olarak öğrencileri düşündürecek ve hedefe yönlendirecek sorular sormuştur. Bu sorularla öğrencilerin zihnen aktif olması ve öğrenme hedefinden ayrılmamaları sağlanmıştır. Ayrıca müzakereyi başlatan, müzakereyi devam ettiren, dikkat çeken ve kontrol amaçlı sorular da öğrencilere yöneltilmiştir. Gruplar küçük grup tartışmalarını gerçekleştirirken bir kararsızlık durumu yaşadıklarında öğretmenlerinden yardım istemişlerdir. Bu aşamada ise öğretmen tekrar soru sorarak öğrencinin daha dikkatli düşünmesini sağlamıştır. Küçük grup tartışmalarının sonunda öğrencilerden yaptıkları deneyleri göz önünde bulundurarak bir iddia oluşturmaları istemiştir. Devamında gruplar iddialarını, delillerini ve bu delillere ulaşmalarını sağlayan deney süreçlerini öğretmen ve diğer gruplardaki öğrencilerle paylaşmışlardır. Bu aşamada da iddiasını sunan grup ile diğer gruplar arasında tartışmalar (ikna süreci) gerçekleşmiştir. İddia paylaşımı gerçekleştiren gruplar, arkadaşlarını ikna etmek için kendi tasarladıkları deneylerden elde ettikleri kanıtlara vurgu yapmış ve hatta bazı durumlarda deney düzenekleri yeniden düzenlenerek paylaşım gerçekleştirmişlerdir. Her aşamada olduğu gibi bu aşamada da öğretmen sürece rehberlik etmiş, tartışmanın hedeften ayrılmamasına özen göstermiş ve gerektiğinde soruları ile tartışmayı yönlendirmiştir. Tüm grupların iddia-delil paylaşımları tamamlandıktan sonra öğretmen konuya ilişkin bazı noktalara dikkat çekmiş ve konuyu özetleyerek dersi tamamlamıştır.

Deney grubunda argümantasyona dayalı aktiviteler gerçekleştirilirken kontrol grubunda Fen Bilimleri dersi araştırmacı tarafından yürütülmüş ve dersler geleneksel yaklaşımla işlenmeye devam etmiştir. Konular düz anlatım ve soru cevap şeklinde işlenmiş ve bazı haftalarda konu içeriğine uygun olarak gösteri deneyleri yapılmıştır. Gösteri deneyleri araştırmacı tarafından gerçekleştirilmiş ve bazı öğrenciler bir yardımcı gibi deneyi gerçekleştirme sürecine dâhil olmuşlardır. Konu anlatımının tamamlanmasının ardından ders kitabında yer alan ünite soruları öğrenciler ile cevaplandırılmıştır. Belirtilen bu uygulamalar bu çalışma kapsamında geleneksel öğretim olarak tanımlanmıştır. Uygulama sürecinin tamamlanmasıyla birlikte hem deney hem de kontrol grubuna "Ünite Tabanlı Başarı Testi” son test olarak uygulanmıştır. Ayrıca deney ve kontrol gruplarından altışar öğrenci olmak üzere 12 öğrenci ile de yarı yapılandırılmış görüşmeler gerçekleştirilmiştir. 


\section{Veri Toplama Araçları}

Ünite tabanlı başarı testi: Çalışma kapsamında “Madde ve Değişim” ünitesi kapsamında 20 çoktan seçmeli ve 5 açık uçlu olmak üzere toplam 25 sorudan oluşan ünite tabanlı başarı testi hazırlanmıştır. Çoktan seçmeli sorular oluşturulurken öğrencilerin seviyelerine uygun çeşitli kitaplar incelenmiştir. Öğrencilerin üniteye ilişkin kavrama düzeylerini derinlemesine ölçmek için belirtilen üniteye ilişkin kazanımlar dikkate alınarak açık uçlu sorular hazırlanmıştır. Oluşturulan soruların ünitenin hedeflenen davranışlarını ölçmeye uygun olup olmadığını belirlemek için ünite kazanımları ve belirtke tablosu oluşturulmuştur. "Madde ve Değişim" ünitesi için oluşturulan ünite tabanlı başarı testi hazırlanırken bütün ünite kazanımlarını kapsayacak şekilde olmasına dikkat edilmiştir. Ayrıca teste yer alan çoktan seçmeli sorulara ilişkin madde güçlük indeksi ve madde ayırt edicilik indeksi değerleri hesaplanmıştır. Testte yer alan soruların güçlük indeksi ve ayırt edicilik indekslerini hesaplamak için öncelikle teste katılan öğrencilerin testten aldıkları puanlar başarı seviyelerine göre sıralanmıştır. Sıralanan puanların en yüksek olduğu grupların \%27'si alınarak üst grup (Nü) ve en düşük olduğu grupların \%27'si alınarak alt grup (Na) olarak adlandırılmıştır. Madde güçlük indeksi (p) p= Dü+Da/Nü+Na formülü, ayırt edicilik indeksi (q) ise q= Dü-Da/Nü formülü ile hesaplanmıştır (Özçelik, 2013; Gelbal, 2013). Elde edilen sonuçlara ilişkin sonuçlar Tablo 1'de yer almaktadır.

Tablo 1. Başarı testi çoktan seçmeli sorulara ilişkin güçlük ve ayırt edicilik değerleri

\begin{tabular}{lcc}
\hline Sorular & Güçlük indeksi (p) & Ayırt Edicilik Indeksi (q) \\
\hline 1 & 0,737 & 0,526 \\
2 & 0,421 & 0,631 \\
3 & 0,684 & 0,684 \\
4 & 0,605 & 0,579 \\
5 & 0,605 & 0,375 \\
6 & 0,842 & 0,105 \\
7 & 0,263 & 0,316 \\
8 & 0,578 & 0,05 \\
9 & 0,131 & 0,316 \\
10 & 0,789 & 0,684 \\
11 & 0,605 & 0,684 \\
12 & 0,658 & 0,526 \\
13 & 0,684 & 0,684 \\
14 & 0,553 & 0,684 \\
15 & 0,658 & 0,789 \\
16 & 0,553 & 0,632 \\
17 & 0,526 & 0,315 \\
18 & 0,315 & 0,158 \\
\hline
\end{tabular}

Test, içerik ve kapsam geçerliliği için bir öğretim üyesi, bir fen bilimleri öğretmeni ve bir yüksek lisans öğrencisi tarafından incelenmiştir. Belirtilen öneriler doğrultusunda testte yer alan ilgili sorularda gerekli düzenlemeler yapılmıştır. Yapılan bu değişikliklerin ardından test son halini almıştır. Son halini alan testin Cronbach's Alfa değeri .84 olarak hesaplanmıştır. Cronbach's Alfa değerinin .80'den yüksek olan testlerin yüksek bir iç tutarlılığa sahip olduğunu söylemek mümkündür (Pallant, 2016). Sorulara ilişkin puanlama yönergesi ise bir fen bilimleri öğretmeni ile birlikte hazırlanmıştır. Açık uçlu soruların puanlanmasının ardından bir fen bilimleri öğretmeni ve bir yüksek lisans öğrencisi tarafından tekrar incelenmiş ve değerlendirilmiştir. Puanlamanın değerlendirilmesine ilişkin görüşler alınarak gerekli değişiklikler yapılmıştır.

Yarı yapılandırılmış görüşme soruları: Görüşmeler bireylerin gözlemleyemediğimiz davranış, düşünce ve duygularını açığa çıkarmak amacıyla yapılır (Patton, 2014). Görüşme sorularının önceden hazırlandığı ve her katılımcıya aynı ifadeleri içeren soruların sorulduğu görüşmeler yapılandırılmış görüşmeler, konuşulması düşünülen konuların belirlendiği bir kılavuzun takip edilmesi ile gerçekleştirilen görüşmeler yarı yapılandırılmış ve belli bir amaç doğrultusunda soruların görüşme esnasında belirlendiği sohbet havasında gerçekleştirilen görüşmeler de yapılandırılmamış görüşmeler olarak ifade edilir (Balcı, 2013; Patton, 2002). Süreç sonunda öğrencilerde meydana gelen değişimleri tespit etmek amacıyla yarı yapılandırılmış görüşmeler gerçekleştirilmiştir. Bu kapsamda öğrencilere “Fen Bilimleri derslerinizde neler yaptınız?, Yaptığınız etkinliklerin size nasıl etkileri oldu?” şeklinde çeşitli sorular yöneltilmiştir. Sorular hazırlanırken öğrencilerin gelişim düzeyleri dikkate alınmış ve çok karmaşık soru cümlelerinin oluşturulmamasına özen gösterilmiştir. Öğrencilerle gerçekleştirilen görüşmeler ses kayıt cihazıyla kayıt altına alınmıştır.

\section{Verilerin Analizi}

Öğrencilerin ünite başarılarını ölçmek için öğrencilerin ünite tabanlı başarı testi ön test ve son test puanları dikkate alınmıştır. Öğrencilerin ön test ve son testten aldıkları puanlar SPSS programında değerlendirilmiştir. Çoktan seçmeli sorular toplam puanı, 
açık uçlu sorular toplam puanı ve testte yer alan soruların toplam puanları ayrı ayrı analiz edilmiştir. Veriler analiz edilmeden önce parametrik test varsayımlarının sağlanıp sağlanmadığı kontrol edilmiştir. Örneklem büyüklüğü, verilerin normal dağılım göstermesi ve varyansların homojen dağılımı varsayımları sağlandığı için verilere parametrik testler uygulanmıştır. Deney ve kontrol gruplarındaki öğrenciler arasındaki puanlarını karşılaştırmak için “betimsel istatistik”, "ilişkisiz örneklemler t-testi” ve "tek faktörlü ANCOVA" analizleri kullanılmıştır.

Uygulama sonunda deney ve kontrol grubunda 6 olmak üzere toplam 12 öğrenci ile yarı yapılandırılmış görüşmeler gerçekleştirilmiştir. Görüşme yapılan öğrencilerin isimleri paylaşılmamıştır. Deney grubu öğrencileri Öd1, Öd2, Öd3... ve kontrol grubu öğrencileri Ök1, Ök2, Ök3... şeklinde kodlanmıştır. Kayıt altına alınan görüşmeler sonrasın-da deşifre edilerek transkript edilmiştir. Elde edilen yazılı veriler "Nvivo11" programında kodlanmıştır. Kodlamalar araştırmacılardan biri tarafından gerçekleştirilmiştir. Fakat kodlamaların geçerliliği ve güvenilirliği için araştırmacılar bir araya gelerek kodlamalar üzerine tartışmışlardır. Verilerin analizi için tematik analiz kullanılmıştır. Analiz süreci tümevarımsal bir bakış açısıyla tamamlanmıştır. Tümevarımsal tematik analiz; araştırma için özel olarak toplanan verilerin tekrar tekrar okunduğu, verilere bağıı kalarak temaların ve kodların oluşturulduğu ve farklı temaların dikkate alınmadığı bir analiz sürecidir (Braun \& Clarck, 2006, s.12). Bu nedenle veriler tekrar tekrar okunmuş ve öğrenci ifadelerinde karşılaşılan her farklı öğrencideki değişim ifadesi için yeni bir kod oluşturulmuştur. Kodlamalarda "öğrencideki değişim" ana teması göz önüne alınarak öğrencilerin öğrenme süreci boyunca kendilerinde meydana gelen değişimleri ne düzeyde yansıttıkları analiz edilmiştir. Yapılan kodlamalara "Nvivo11" programında çeşitli analizler uygulanarak kodlamalar görsel öğeler ile somutlaştırılmıştır.

\section{BULGULAR}

\section{Nicel Bulgular}

Uygulamalar öncesinde grupların “Madde ve Değişim” ünitesine yönelik başarıları arasında anlamlı bir farkın olup olmadığını tespit etmek amacıyla ünite tabanlı başarı testi, ön test olarak uygulanmıştır. Test sonucunda elde edilen veriler ilişkisiz (bağımsız) örneklemler için t-testi ile analiz edilmiştir. Grupların ünite tabanlı başarı testine ilişkin ortalamaları ve standart sapmaları Tablo 2'de yer almaktadır.

\section{Tablo 2. Başarı testi ön testine ilişkin bulgular}

\begin{tabular}{|c|c|c|c|c|c|c|}
\hline Ön Test & Gruplar & $\mathrm{N}$ & $\bar{x}$ & Ss & t-değeri & $p$ \\
\hline \multirow[t]{2}{*}{ ÇSSTP* } & Kontrol & 39 & 27.00 & 9.36 & -0.932 & 0.354 \\
\hline & Deney & 39 & 24.85 & 11.12 & & \\
\hline \multirow[t]{2}{*}{ AUSTP* } & Kontrol & 39 & 3.80 & 2.66 & 0.678 & 0.500 \\
\hline & Deney & 39 & 4.32 & 3.94 & & \\
\hline \multirow[t]{2}{*}{ Test Toplamı } & Kontrol & 39 & 30.80 & 9.92 & -0.112 & 0.911 \\
\hline & Deney & 39 & 29.17 & 12.24 & & \\
\hline
\end{tabular}

ÇSSTP*: Çoktan Seçmeli Soru Toplam Puanı, AUSTP*: Açık Uçlu Soru Toplam Puanı

Tablo 2 incelendiğinde, gruplar arasında çoktan seçmeli sorular toplam puanı $(t(78)=-0.932, p=0.354)$, açık uçlu sorular toplam puanı $(t(78)=0.678, p=0.500)$ ve test toplam puanları $(t(78)=-0.112, p=0.911)$ açısından anlamlı istatistiki farklılık tespit edilmemiştir. Bu sonuç her iki grubunda “Madde ve Değişim” ünitesi başarısı açısından benzer olduklarını göstermektedir. Ancak grupların testten aldıkları ortalama puanlarda istatistiksel olarak anlamlı olmasa da küçük farklılıklar olduğu tespit edilmiştir. Hata varyansını azaltmak, daha güçlü bir istatistiksel test elde etmek, deney ve kontrol grubu arasındaki ilk farklılıkları istatistiksel olarak telafi etmek için başarı testinin ön test puanı ortak değişken olarak kullanılmıştır. Deney ve kontrol grubu öğrencilerinin başarı testi ön test puanlarına göre düzeltilmiş son test ortalama puanları Tablo 3'de yer almaktadır. Düzeltilmiş ortalama (estimated marginal means) gruplarımızın her biri için bağımlı değişken üzerinden ayarlanmış ortalamaları sağlar. "Düzeltilmiş" ortak değişkenin etkisinin istatistiksel olarak ortadan kaldırıldığı gerçeğini ifade etmektedir (Pallant, 2015). Grupların son test ANCOVA analizine ilişkin bulguları ise Tablo 4'de verilmiştir.

Tablo 3. Başarı testi son testine ilişkin bulgular

\begin{tabular}{lccccc}
\hline Ön Test & Gruplar & $\mathrm{N}$ & Ortalama & Düzeltilmiş Ortalama & $\mathrm{p}$ \\
\hline ÇSSTP* & Kontrol & 39 & 27.45 & 26.74 & 0.354 \\
& Deney & 39 & 33.85 & 34.57 & \\
AUSTP* & Kontrol & 39 & 3.75 & 4.11 & 0.500 \\
& Deney & 39 & 11.50 & 11.11 & \\
Test Toplamı & Kontrol & 39 & 34.25 & 33.59 & 0.911 \\
& Deney & 39 & 48.38 & 49.07 & \\
\hline
\end{tabular}

ÇSSTP*: Çoktan Seçmeli Soru Toplam Puanı, AUSTP*: Açık Uçlu Soru Toplam Puanı

Tablo 3'de grupların çoktan seçmeli, açık uçlu ve test toplamından aldıkları ortalama ve düzeltilmiş ortalama puanları yer almaktadır. Her üç puan türünde de deney grubunun puan ortalamalarının kontrol grubundan daha yüksek olduğu görülmektedir. 
Grupların son test ANCOVA analizine ilişkin bulguları ise Tablo 4'de verilmiştir. Son test verilerine ANCOVA analizi uygulanırken ön test puanları (çoktan seçmeli sorular toplam puanı, açık uçlu sorular toplam puanı ve test toplam puanı) ortak değişken olarak kullanılmıştır.

Tablo 4. Son test ANCOVA analizine ilişkin bulgular

\begin{tabular}{|c|c|c|c|c|c|c|c|}
\hline Ön Test & Varyansın Kaynağı & Karelerin Toplamı & $\mathrm{Sd}$ & Karelerin Ortalaması & $\mathrm{F}$ & $\mathrm{P}$ & $\eta_{p}{ }^{2}$ \\
\hline \multirow[t]{4}{*}{ ÇSSTP* } & Ön Test & 3603.181 & 1 & 3603.181 & 24.684 & 0.000 & 0.245 \\
\hline & Grup & 1197.505 & 1 & 1197.505 & 8.204 & 0.005 & 0.097 \\
\hline & Hata & 11093.796 & 76 & 145.971 & & & \\
\hline & Toplam & 15504.835 & 78 & & & & \\
\hline \multirow[t]{4}{*}{ AUSTP* } & Ön Test & 1030.616 & 1 & 1030.616 & 53.090 & 0.000 & 0.442 \\
\hline & Grup & 847.373 & 1 & 847.373 & 43.651 & 0.000 & 0.394 \\
\hline & Hata & 1300.634 & 76 & 19.412 & & & \\
\hline & Toplam & 3381.486 & 78 & & & & \\
\hline \multirow[t]{4}{*}{ Test Toplamı } & Ön Test & 7648.600 & 1 & 7648.600 & 81.469 & 0.000 & 0.549 \\
\hline & Grup & 4173.455 & 1 & 4173.455 & 44.454 & 0.000 & 0.399 \\
\hline & Hata & 6290.179 & 76 & 93.883 & & & \\
\hline & Toplam & 17431.086 & 78 & & & & \\
\hline
\end{tabular}

ÇSSTP*: Çoktan Seçmeli Soru Toplam Puanı, AUSTP*: Açık Uçlu Soru Toplam Puanı

Tablo 4' de yer alan ANCOVA analizine ait bulgular incelendiğinde ise gruplar arasında test toplam puanlarının $(F(1,78)=44.454$, $\left.p=0.000, \eta_{p}{ }^{2}=0.399\right)$ yanı sıra çoktan seçmeli sorular toplam puanı $\left(F(1,78)=8.204, p=0.005, \eta_{p}{ }^{2}=0.097\right)$ ve açık uçlu sorular toplam puanı $\left(F(1,78)=43.651, p=0.00, \eta_{p}{ }^{2}=0.394\right)$ açısından istatistiki olarak anlamlı farklılıklar olduğu tespit edilmiştir. ANCOVA analizi sonucunda elde edilen kısmi eta kare $\left(\eta_{\mathrm{p}}{ }^{2}\right)$ değeri incelendiğinde ise deney grubunun kontrol grubundan farkı olan argümantasyon uygulamalarının, başarı testinin ön test değişkeninden bağımsız olarak son test puanlarındaki değişkenliğin \%39.9'unu açıkladığı görülmektedir. Deney grubundaki öğrencilerin son test toplam puanının kontrol grubu öğrencilerinin puanlarına göre daha yüksek olduğu belirlenmiştir. Deney grubunda gerçekleştirilen argümantasyon uygulamalarının öğrencilerin ünite başarılarını olumlu etkilediği söylenebilir.

\section{Nitel Bulgular}

Analiz sonucunda elde edilen bulgular Tablo 5'de özetlenmiştir. Bu tabloya göre hem deney grubu hem de kontrol grubu öğrencilerinin en fazla öğrenme ve kalıcılığa vurgu yaptıkları dikkat çekmektedir. Deney grubu öğrencileri bunlara ek olarak bilgiyi somutlaştırma, fen dersini sevme, derse odaklanma gibi değişimleri de ifade ettikleri görülmektedir. Oluşturulan temalara ilişkin öğrenci görüşleri tablonun devamında yer almaktadır.

Tablo 5. Tematik analize ilişkin bulgular

\begin{tabular}{|c|c|c|c|}
\hline Tema & Gruplar & Kodlar & $\mathrm{F}$ \\
\hline & & Öğrenme & 6 \\
\hline & & Kalıcılık & 4 \\
\hline & & Bilgiyi somutlaştırma & 3 \\
\hline & Ronou Grubu & Fen dersini sevme & 2 \\
\hline & Deney orudu & Deney yapmayı sevme & 2 \\
\hline \multirow[t]{6}{*}{ Bireysel Değişim } & & Derse odaklanma & 2 \\
\hline & & Dikkatli olma & 1 \\
\hline & & Öz güveni artırma & 1 \\
\hline & & Öğrenme & 5 \\
\hline & Kontrol Grubu & Kalıcılık & 3 \\
\hline & & Derse odaklanamama & 2 \\
\hline
\end{tabular}

Deney grubu nitel bulguları: Öğrenciler görüşmelerde kendilerinde olan değişimleri; daha iyi öğrenme, öğrendikleri bilgilerin kalıcılığı, bilgileri somutlaştırma, derse odaklanma, fen dersini sevme, deney yapmayı sevme, ders boyunca dikkatli olma ve öz güveni artırma olarak ifade etmişlerdir. Argümantasyon sürecinde öğrenciler; küçük grup ve sınıf olarak gerçekleştirilen deneylerin ve tartışmaların öğrenmelerine katkı sağladığını dahası bu öğrendiklerinin daha uzun süre akılda kaldığını ifade etmişlerdir. Öğrenciler, bu süreçte deneylerin bilgileri somutlaştırarak daha iyi öğrenmelerine katkı sağladığını vurgulamışlardır. Bu durumu Öd4 "...Laboratuvarda daha ayrıntılı görüyoruz. Sınıfta da daha ayrıntılı ama burada deney yaptığımız ve gözümüzle neler olduğunu gördügümüz için daha etkili oldu, daha iyi oldu..." ifadesi ile belirtmiştir. Öd1 ise "... Deney yaparak daha iyi öğreniyoruz benim için daha etkili oldu hem de eğlenerek öğreniyoruz..." ifadesi ile hem derslere aktif olarak katıldığı için hem de dersten zevk aldığı için 
daha iyi öğrendiğini vurgulamıştır. Öğrenciler süreç boyunca gerçekleştirdikleri etkinliklerin yanlış bilgileri düzeltmelerine ve deneyde kullanılan malzemeleri doğru bir şekilde kullanmayı öğrenmelerine katkı sağladığını belirtmişlerdir. Bu durumu Öd2'nin "...Mesela dinamometre nasıl çalışır falan diyor. Biz alıyoruz dinamometreyi ama yanlış mı ölçüyor doğru mu? kimse bilmiyor. Ama deneyleri yaptıkça doğru kullanmayı falan öğreniyoruz..." ifadesi ile vurgulamıştır. Öğrenciler akranlarının değerlendirmelerini dikkate aldıklarını, kendi buldukları sonuçları ile diğer sonuçları karşılaştırdıklarını, bu değerlendirmelerle kendi sonuçlarını kontrol ettiklerini ve bir sorgulama süreci yaşadıklarını belirtmişlerdir. Bu süreçte öğrenciler, hem diğer grupların hem de kendi deney sonuçlarını sorguladıklarını vurgulamışlardır. Öğrenciler süreçte deneylerde bazı malzemelerin benzer olmasına rağmen sonuçların farklı olmasını sorgulamışlar ve deneye etki eden diğer değişkenleri de dikkate almışlardır.

Öğrenciler grup içerisinde farklı fikirlere saygı duyduklarını ve bu farklı fikirlerden hareketle ortak bir karara varma becerilerinin arttığına dikkat çekmişlerdir. Bu durumu Öd2 “... Biri kendi fikri olsun diye ısrar ediyor ama gruptaki farklı fikirlerin hepsini toplayarak bir fikir yarattığımızda oldu... Işste bizim orda hepimizin önerisini toplayıp bir sonuç çıkarma becerimiz oldu..." ifadeleri ile vurgulamıştır. Öğrenciler argümantasyon sürecine uygun deneyler gerçekleştirilirken kendi merak ettikleri soruları araştırmış, bu sorulara cevaplar bulmak için deneyler tasarlamış, küçük gruplarında deney ve sonuçlar hakkında tartışmalar gerçekleştirmiş ve elde ettikleri sonuçları diğer gruplar ile paylaşmışlardır. Süreçte gerçekleştirdikleri bu etkinlikler boyunca öğrenciler zihnen aktif oldukları için dikkatlerini toplayabildiklerini ve derse daha kolay konsantre olduklarını görüşmeler esnasında belirtmişlerdir. Bunları yaparken anlamadığı konuları da daha iyi öğrendiklerini vurgulamışlardır. Öd5'in “...Anlamadığımız konularda deneyler yaparak daha iyi anladım ve derse odaklanmada zorluk yaşamadım..." ve Öd2'nin "... Odaklanmamızı güçlendirdi bence deneyler... Bunlar bizim dikkatimiz geliştirdi..." ifadeleri bu durumu yansıtmaktadır. Öğrenciler deneylerin bilgilerin test edilmesi için bir araç olduğunu görüşmeler esnasında ifadeleri ile vurgulamışlardır. Öd5” in belirttiği “Bence hani iddia oluşturuyoruz, notlar alıyoruz ve de hani o notları deneyerek görüyoruz doğruluğunu veya yanlışığını. Böylelikle de iddiamızı ortaya koyuyoruz. Hani bu sayede daha iyi anlama kabiliyetimiz gelişebilir, daha iyi olabilir." ifadesi ile sürecin bilgiyi test etme imkânı vermesi ve bilgiyi anlamayı olumlu etkilediğini vurgulamaktadır.

Argümantasyon sürecinde öğrenciler küçük gruplarda deneylerini gerçekleştirip, iddialarını oluşturup, tartışmalardan ve deneyden elde ettikleri sonuçlar ile raporlarını tamamlarlar. Ardından öğrenciler büyük grup tartışmalarında iddialarını diğer arkadaşları ile paylaşıp iddialarını kanıtlamaya çalışmaktadırlar. Bu sırada sınıfta bulunan diğer öğrenciler ikna olmak için gruba deneyle ilgili sorular sorup karşı argümanlar oluştururlar. Görüşmeler esnasında öğrencilere bu sürece ilişkin ne düşündükleri ve ne hissettikleri sorulduğunda Öd1 şu ifadeleri kullanmıştır: “... Grup iddiamızı sunmak iyi açıdan etkiledi. Çünkü sunum yaptığım zaman daha çok aklımda kalıyor. Onu ben anlatıyorum orda. Mesela öğretmenler hiç unutmaz. Kaç kere anlattıkları için o yüzden ben orda anlattığım için benim de orda aklımda kalıyor... Öğretmene sorular soruyorlar ya, bana da soru sordukları için kendimi öğretmen gibi hissettim...". Öğrenciler argümantasyon uygulamaları boyunca merak ettikleri ve ihtiyaçları olan bilgileri araştırdıkları için bilgileri özümseyerek öğrenmeyi gerçekleştirdiklerini ifade etmektedirler.

Geleneksel yaklaşıma kıyasla argümantasyon sürecinde öğrenciler öğrenme sürecine aktif bir şekilde dâhil olurlar. Öğrencilerin çoğu görüşmelerinde argümantasyon sayesinde derslerin daha zevkli geçtiğini ve fen dersini daha çok sevdiklerini belirtmişlerdir. Öd1 “...Fen derslerini önceden sevmiyordum. Önceden matematik derslerini seviyordum... Yaptığımız deneyler ve öğretmenlerimizin davranışları sayesinde fen dersini sevmeye başladım..." ifadesi ile fen dersini etkinlikler ile birlikte sevmeye başladığını vurgulamıştır. Öğrenciler görüşmelerde uygulamanın ilk haftalarında deneyleri yapamayacaklarını düşünüp sürece fazla dahil olamadıklarını ancak sonraki haftalarda ise bu korkularını yendiklerini belirtmişlerdir. Öd6’nın “...Mesela kendim kalkıp fikirlerimi sunuyordum bazen doğru bazen de yanlış çıkabiliyordu. Ben sadece fikrimi sunuyordum... Deneylerin bazılarında zorlanmıştım. Yapamam diye korkuyordum. Yapamam korkusu vardı. Ama deneyler devam ettikçe geçti. Son deneyde çok az zorlandım. Onunda korkusunu yendim..." ifadeleri bu durumu yansıtmaktadır.

Kontrol grubu nitel bulguları: Öğrencilere derslerin kendilerine neler kattığı sorulduğunda üç öğrenci, öğrendikleri bilgilerin kalıcılığını belirtmiştir. Ancak bilgilerin kalıcı olması için öğrencinin sıklıkla tekrarlar yapması gerektiğini, derste öğretmeni iyi dinlemesi gerektiğini belirtmişlerdir. Ök3 “...Bence kalıcı oluyor, birde arada unutmuş gibi olduğunda tekrar ettiğine yüzde yüz kalıyor..." ifadesi ile bilgilerin kalıcı olması için tekrarın da önemli olduğunu belirtmiştir. Bazı öğrenciler ise dönem ilerledikçe ilk öğrendiği bilgileri unuttuğunu, fazla hatırlamadıklarını belirtmişlerdir. Bu durumu Ök6 “...Bu dönem ağırlıklı işleyince insan biraz unutuyor..." ifadeleri ile vurgulamıştır. Öğrenciler görüşme esnasında derslerde bazen konunun yapısına uygun olarak deneyler yaptıklarını belirtmişlerdir. Ancak bu deneyleri öğretmenin yaptığını kendilerinin ise ya izlediklerini ya da yardımcı olarak deneye dâhil olduklarını belirtmişlerdir. Bu duruma rağmen öğrencilerin gösteri deneylerinin yapıldığı konulardan bahsederken hiç zorlanmadıkları ve neredeyse bütün detayları hatırladıkları dikkat çekmiştir. Örneğin bu durumu Ök6 “...Deneyler yapıyoruz. Bir kere bir tane halka vardı onun içinden ısıtarak geçirmeye çalışmıştık ama geçmemişti. Isıttığımız için büyümüştü halka. Demir olduğu için... Ona benzer deneyler yapıyoruz..." ifadesi ile vurgulamıştır. Gösteri deneylerinin bilgileri öğrenmede ders anlatımından daha etkili olduğunu ve öğrenilen bilgilerin daha kalıcı olduğu vurgulanmıştır. Ök4 ise "...Geçen dönem karbonhidratları ve proteinleri işlemiştik. Öğretmenimiz bizi laboratuvara çağırmıştı, biz de yanımızda yiyecek getirmiştik mesela ceviz falan. Baya bilgim oldu. Laboratuvarı çok seviyorum çok güzel bir yer orda ders işlemek çok zevkli..." ifadeleri ile laboratuvar ortamında bulunmayı ve orada deneyler yapmayı sevdiğini belirtmiştir.

Öğrenciler de derslerde konunun anlatıldı̆̆ını, konuya ilişkin çok fazla örneklerin verildiğini, konuyla ilgili testlerin çözüldüğünü ve son olarak ders kitabında yer alan değerlendirme sorularını çözdüklerini belirtmişlerdir. Ök3 “...Bazen yazı yazıyoruz, ondan sonra hoca bize anlatıyor, arada test falan çözüyoruz, arada ödev falan veriyor..." ifadeleri ile bu durumu yansıtmaktadır. 
Öğrenciler derslerde öğretmenlerinin eğlenceli şeyler yaptırarak dikkatlerini çekmeye çalıştıklarını vurgulamıştır. Öğrenciler de bu sayede eğlenerek öğrendiklerini ve dersten zevk aldıklarını belirtmişlerdir. Ök1 “... Bir keresinde yağmur olun dediğinde sıraların üstüne çıkıp atlamıştık. Buharlaşın dediğinde de sıranın üstüne çıkmıştık, katı olun dediğinde arkadaşlarımızla sarılmıştık..." ifadeleri ile bu durumu vurgulamıştır. Bunların yanı sıra öğrenciler ders esnasında sıklıkla dikkatlerinin dağıldığını belirtmişlerdir. Ök2'nin “...Bazı şeylerde falan dikkatim dağılıyor. Başka şeylere odaklanıyorum diyelim biri hareket etti direk ona bakıyorum niye hareket etti diye ya da içeri biri girse..." ve Ök5'in "...Sınıftakiler bazen konuşuyor, konuştuğunda da herkes o tarafa bakıyor bazıları da söylüyor sessiz olsanıza diyor dikkatimiz dağılıyor..." ifadeleri ile bu durumun ders esnasında sıklıkla yaşandığını vurgulamışlardır.

\section{TARTIŞMA}

Çalışma kapsamında gerçekleştirilen argümantasyon uygulamalarının ortaokul beşinci sınıf öğrencilerinin ünite başarılarına ve bireysel değişimlerine etkisi incelenmiştir. Argümantasyon uygulamaları ISı, sıcaklık, maddelerin hal değişimi gibi konuları içerisinde barındıran "Madde ve Değişim” ünitesi kapsamında gerçekleştirilmiştir. Çalışmada belirtilen üniteye yönelik çoktan seçmeli ve açık uçlu sorulardan oluşan bir başarı testi hazırlanmış ve testin güvenilirliğine ilişkin gerekli istatistiksel analizler yapılmıştır. Ardından ölçme aracı ön ve son test olarak öğrencilere uygulanmıştır. Uygulamaların tamamlanmasının ardından deney ve kontrol gruplarından altışar olmak üzere toplam 12 öğrenciyle yarı yapılandırılmış görüşmeler gerçekleştirilmiştir. Başarı testinde yer alan açık uçlu ve çoktan seçmeli sorular ayrı ayrı analiz edilmiştir. Görüşmelerden elde edilen verilere ise içerik analizi uygulanmıştır. Elde edilen bulgular incelendiğinde uygulama öncesinde deney ve kontrol grubunda yer alan öğrencilerin açık uçlu ve çoktan seçmeli sorular toplam puanları açısından farklılaşmadıkları tespit edilmiştir. Beş hafta boyunca gerçekleştirilen etkinlikler sonunda her iki grubunda "Madde ve Değişim” ünitesine ilişkin başarılarının arttığını söylemek mümkündür. Bununla beraber son test bulgularında çoktan seçmeli sorular, açık uçlu sorular ve test toplam puanları açısından deney grubunun kontrol grubundan istatistiki olarak anlamlı bir şekilde farklılaştığı tespit edilmiştir. Özellikle açık uçlu soruların son test ortalama puanları açısından deney grubunun kontrol grubundan daha yüksek ortalamaya ulaştığı tespit edilmiştir. Nitel verilerden elde edilen bulgular incelendiğinde ise argümantasyon uygulamalarına katılan öğrencilerin başarının yanı sıra farklı alanlarda da gelişim gösterdikleri söylenebilir. Argümantasyon uygulamaları boyunca deney grubu öğrencileri akranları ve öğretmenleriyle birlikte üniteye ilişkin kavramları kullanarak müzakere süreci yaşamışlar ve kavramlar arasında ilişki kurarak bilgileri yapılandırmışlardır. Bu doğrultuda argümantasyon uygulamalarının beşinci sınıf öğrencilerinin ünite başarılarını artırmada ve çok yönlü gelişimlerine olanak sağladığı söylenebilir.

Peki deney grubu öğrencilerdeki bu başarı artışının temel noktaları neler olabilir? Duschl ve Osborne (2002)'na göre argümantasyon, mutlak bir doğruya ulaşma çabasından çok, bir duruma ilişkin öne sürülen iddiaların, elde edilen veriler ışığında delillerle birlikte desteklenmesi veya karşı çıkılması, olaylar ve fikirler arasındaki mantıksal ilişkinin belirlenmesi sürecidir. Bu doğrultuda bir argümantasyon etkinliği boyunca, öğrenciler alternatif düşünceleri kanıtlara dayalı olarak değerlendirir, fikirler ve kanıtlar arasındaki ilişkiyi gerekçelendirir, fikirlere ilişkin karşıt argümanlar oluşturur ve son olarak varılan sonucu değerlendirirler. Belirtildiği gibi süreç boyunca bir iddiayı oluşturma ve iddiayı savunmak için öğrenciler ön bilgilerini kullanır ve sürecin her aşamasında karar verme becerilerini kullanma durumunda kalırlar (Hand, Wallace \& Yang, 2004). Bu sayede öğrenciler yeni bilgileri yapılandırmanın yanı sıra karar verme gibi üst düzey düşünme becerileri de kazanma imkânı bulabilmektedirler. Ayrıca argümantasyon sürecinde öğrenciler deney tasarlama ve uygulama faaliyetleri de yürütmüşlerdir. Bu faaliyetlerin öğrencilerin ölçme, ölçme aracını doğru kullanma, değişkenleri test etme gibi bilimsel süreç becerilerini de desteklediğini söyleyebiliriz.

Yeni bilgilere ulaşmada argümantasyonun bileşenlerinden olan "sorgulama” önemli bir yer tutmaktadır (Kabataş-Memiş ve Seven, 2015). Neyi, niçin yaptığının farkında olan öğrenciler argümantasyon süreci boyunca aktif bir şekilde zihinlerinde ön öğrenmeleri ile ilişkili olarak yeni bilgileri yapılandırırlar. Araştırma-sorgulamaya dayalı öğrenmenin yeni bilgileri yapılandırmanın yanı sıra öğrencilerin bilimsel süreç becerilerini geliştirdiği (Kaya ve Yılmaz, 2016), bilime ve bilim insanına yönelik bakış açılarını olumlu etkilediği (Yaşar ve Duban, 2009), öğrencilerin üst biliş ve öz düzenleme becerileri üzerinde etkili olduğu (Varlı, 2018) ve öğrencilerin argümantasyon seviyelerini artırdı̆̆ına (Aktaş ve Doğan, 2018) yönelik çalışmalar yer almaktadır. Argümantasyon da araştırma-sorgulamayı temel almakta ve aynı süreçleri içerisinde barındırmaktadır. Argümantasyon boyunca öğrencilerin muhakeme becerilerinin geliştiği ve dolaysıyla da öğrenme kalitelerinin ve kavramsal gelişimlerinin artığı belirtilmektedir (McNeill \& Knight, 2011). Argümantasyon sürecindeki sorgulamalar boyunca öğrenciler bir problem durumuna ilişkin deney planlama, uygulama, deney sonuçlarını değerlendirme ve sonuçlar doğrultusunda iddialar öne sürerler. Öğrenciler sürekli olarak karşılaştıkları bilgi veya fikirleri sorgulayarak kabul edip etmemeye karar verirler. Bu noktada öğretmen sorularıyla sorgulama sürecine katkı sağlayabilir. Tek bir cevabın olmadığı, "evet-hayır" gibi kısa cevaplı soruların yerine öğrencilerin zihinsel ilişkiler kurarak cevaplayabileceği soruların sorulması önemlidir. Görüldüğü gibi Fen Bilimleri derslerine sorgulamadan temel alan argümantasyon uygulamalarının dahil edilmesi öğrencilerin başarıları ve kavram öğrenme düzeylerini artırmanın yanı sıra öğrenilen bilgilerin kalıcılığı, fen dersine yönelik olumlu tutum geliştirme, soyut bilgilere ilişkin daha somut bir anlayış geliştirme gibi farklı gelişim alanlarında da etkili olmaktadır. Argümantasyon etkinlikleriyle gerçekleştirilen fen dersleri öğrencilerin kendilerini daha kolay ifade etmelerine yardımcı olur ve öğrencilerin kendilerinden emin ve öz güvenli bir şekilde sürece dâhil olmalarını sağlar.

Öğretmenin aktif bir şekilde dersi anlattığı öğrencinin pasif olarak dinlediği bir öğrenme ortamında öğrencilere düşünme, sorgulama, tartışma, akran veya öğretmenle iletişim kurma, karar verme, problem çözme gibi zihinsel aktivitelere katılma imkânın 
verilmediğini söylemek mümkündür. Aksine argümantasyona dayalı bir öğrenme ortamında öğrencilerin daha fazla düşünmesi, tartışması, iletişim kurmasının yanı sıra karar vermesi ve problemlere çözüm üretmeleri teşvik edilmektedir. Bilimsel bilgilerin oluşturulmasında önemli bir yere sahip olan söylem; öğrencilerin alternatif açıklamaları değerlendirmesi ve bu açıklamalardan hangisini, neden seçtiğini açıklamasını içerir. Söylem boyunca öğrenciler, akranlarına meydan okuyarak, kuşkularını ifade ederek, alternatifler sunarak ve bu seçenekleri değerlendirerek daha net bir kavramsal anlayışa sahip olurlar (Driver, Newton \& Osborne, 2000). Ayrıca Erduran ve Jimenez-Aleixandre (2007) söylem etkinlikleri boyunca gerçekleştirilen diyalogların üst düzey düşünceyi geliştirmede güçlü bir araç olduğu ifade edilmektedir. Argümantasyon uygulamaları kapsamında geçekleştirilen bilimsel söylemler sayesinde öğrenciler karşılaştıkları problemlere çözüm üretme, birden çok seçenek arasından ortak bir karara varma, farklı fikirlere açık olmak ve bu fikirleri değerlendirme gibi birçok etkinliğe dâhil olurlar. Tüm bu nedenlerden dolayı argümantasyona dayalı öğrenme ortamlarda öğrencilerin bilgileri yapılandırdıkları, bu bilgileri gerekli durumlarda kolaylıkla kullanabildikleri, üst düzey düşünme, bilimsel süreç becerileri, tutum gibi çok yönlü gelişimlerine imkân sağladığını söylemek mümkündür.

\section{SONUÇ VE ÖNERILER}

Yukarıda ifade edilenler göz önüne alındığında öğrencilere sorgulama, eleştirel düşünme, karar verme, problem çözme gibi üst düzey düşünme becerilerinin yanı sıra doğru ve güvenilir bilgilere ulaşabilme yetkinliklerinin kazandırılması önemlidir. Bu nedenle bireylerin okul öncesi dönemden itibaren bu özellikleri kazandırabilecek öğrenme ortamlarında bulunmaları önemlidir. Bu sayede güvenilir bilgilere ulaşabilen, doğru kararlar alabilen, zihninde bilgileri yapılandırabilen ve gerektiğinde karşılaştığı problemlerin çözümünde kullanabilen bireylerin yetiştirilmesine katkı sağlanabilir. Belirtilen bu yetkinliklere sahip öğrencilerin yetiştirilmesi, bu beceri ve yetkinliklere sahip öğret-menlerle mümkün olacaktır. Özellikle öğretmen yetiştirme kurumlarında bu durumlar göz önüne alınarak eğitim-öğretimde bir yeniliğin yapılması önerilebilir. Ayrıca hizmette olan öğretmenlerin alanları ile ilgili son gelişmeler konusunda haberdar edilmesi ve eğitim araştırmalarına dâhil edilmesi önerilebilir. Sonraki çalışmalarda argümantasyon uygulamalarının farklı sınıf seviyelerinde gerçekleştirilmesi, bu uygulamanın öğrencilerde meydana getirdiği değişimlerin ve argümantasyon uygulamalarına yönelik öğretmen görüşlerinin incelendiği çeşitli nitel araştırmalar yapılabilir. Fen bilimleri öğretim programlarında da geniş yer bulan ve 21. yüzyıl becerileri olarak ifade edilen ve yaşam becerileri, işgücü becerileri, uygulamalı beceriler, kişisel beceriler, kişilerarası beceriler ve bilişsel olmayan beceriler öğrencilerin bireysel gelişimleri açısından oldukça önemlidir. Argümantasyon etkinliklerinin kavramsal gelişim ve başarı artışına etkisinin incelendiği çalışmaların yanı sıra yukarıda ifade edilen 21. yüzyıl becerileri üzerindeki etkileri de incelenebilir.

\section{KAYNAKÇA}

Akkuş, R., Günel, M., \& Hand, B. (2007). Comparing an inquiry-based approach known as the science writting heuristic to traditional science teaching practics: are there differences? International Journal of Science Education, 29(14), 1745-1765. doi: 10.1080/09500690601075629.

Aktaş, T. ve Doğan, Ö. (2018). Argümana dayalı sorgulama öğretiminin 7. sınıf öğrencilerinin akademik başarılarına ve argümantasyon seviyelerine etkisi. Mersin Üniversitesi Eğitim Fakültesi Dergisi , 14(2), 778-798. doi: 10.17860/mersinefd.342569.

Banilower, E., Cohen, K., Pasley, J. \& Weiss, I. (2010). Effective science instruction: What does research tell us? Second edition. Porsmouth: RMC Research Corporation, Center on Instruction.

Bozkurt, O. (2012). Fen eğitiminde araştırmaya dayalı öğrenme yaklaşımının öğrencilerin akademik başarılarına ve bilimsel süreç becerilerine etkisi. Mustafa Kemal Üniversitesi Sosyal Bilimler Enstitüsü Dergisi, 9(18), 187-200.

Christensen, L. B., Johnson, B., Turner, L. A., \& Christensen, L. B. (2014). Research methods, design, and analysis. Pearson Education.

Çepni, S. (2012). Araştırma ve proje çalışmalarına giriş (6. Baskı.). Trabzon. Celepler Matbaacılık.

Driver, R., Newton, P. \& Osborne, J. (2000). Establishing the norms of scientific argumentation in classroom. Science Education, 84(3), $287-312$. doi: 10.1002/(SICI)1098-237X(200005)84:3<287::AID-SCE1>3.0.CO;2-A.

Duschl, R. \& Osborne, J. (2002). Supporting and promoting argumentation discourse in science education. Studies in Science Education, 38(1), 39-72. doi: 10.1002/(SICI)1098-237X(200005)84:3<287::AID-SCE1>3.0.CO;2-A.

Erduran, S. \& Jimenez-Aleixandre, M. (2007). Argumentation in science education: An overwiev. Springer.

Günel, M., Kabataş Memiş , E. ve Büyükkasap , E. (2010). Yaparak yazarak bilim öğrenimi-YYBÖ yaklaşımının ilköğretim öğrencilerinin fen akademik başarısına ve fen dersine yönelik tutumuna etkisi. Eğitim ve Bilim, 35(155), 49-62.

Hand B. M., (2008). Introducing the science writing heuristic approach. B. M., Hand (Ed.). Science Inquiry, Argument and Language.( pp.111).Sense Published.

Hand, B., Wallace, C. \& Yang, E. (2004). Using a science writting heuristic to enhance learning outcomes from laboratory activities in seventhgrade science: Quantitative and qualitative aspects. International Journal of Science Education, 26(2), 131-149. doi: 10.1080/0950069032000070252.

Jill, L. (2007). Inquiry-based learning. Schreyer Institute for Teaching Excellence. University Park, Penn State, Pennsylvania.

Kabataş Memiş, E. ve Çakan Akkaş, B. N. (2016). Okulöncesi eğitiminde araştırma-sorgulama temelli uygulama: yoğunluk konusu örneği. Online Fen Eğitimi Dergisi, 1(1), 17-29.

Kabataş Memiş, E. \& Seven, S. (2015). Effects of an SWH approach and self-evaluation on sixth grade students learning and retention of an electricity unit. International Journal of Progressive Education, 11(3), 32-49. 
Kaya, G. ve Yılmaz, S. (2016). Açık sorgulamaya dayalı öğrenmenin öğrencilerin başarısına ve bilimsel süreç becerilerinin gelişimine etkisi. Hacettepe Üniversitesi Eğitim Fakültesi Dergisi, 31(2), 300-318. doi:10.16986/HUJE.2016016811.

Keselman, A. (2003). Supporting inquiry learning by promoting normative understanding of multivariable causality. Journal of Research in Science Teaching, 40(9), 898-921. doi:10.1002/tea.10115

Kuhn, D. (2009). Teaching and learning science as argument. Science Education, 810-824. doi:10.1002/sce.20395.

McNeill, K. \& Knight, A. (2011). The effect of professional development on teachers' beliefs and pedagogical content knowledge for scientific argumentation. In Paper presented at the annual meeting of the National Association for Research in Science Teaching. Orlando.

MEB. (2013). Fen bilimleri dersi öğretim programı. Ankara: Talim Tebiye Kurulu Başkanlığı.

MEB. (2018). Fen bilimleri dersi öğretim programı. Ankara.

Osborne, J., Erduran, S., Simon, S. \& Monk, M. (2001). Enhancing the quality of argument in school science. School Science Review, 82(301), 6370.

Pallant, J. (2016). SPSS survial manual: A step by step guide to data analysis using IBM SPSS. (S. Balcı, \& B. Ahi, Çev.). Ankara: Anı Yayıncılık.

Toulmin, S. (1958). The uses of argument. Cambridge University Press.

Ulu, C. \& Bayram, H. (2015). Effects of teaching method based on the science writing heuristic approach on science process skills. Hacettepe University Journal of Education, 30(1), 282-298.

Varlı, B. (2018). Araştırma sorgulamaya dayalı öğrenme yaklaşımının fen başarısı, sorgulama, üst biliş ve öz düzenleme becerilerine etkisi. Yüksek Lisans Tezi. Amasya Üniversitesi Fen Bilimleri Enstitüsü, Amasya.

Walker, J. \& Sampson, V. (2013). Learning to argue and arguing to learn: Argument-driven inquiry a as way to help undegraduate chemistry srudents learn how to construct arguments end engage in argumentation during a laboratory course. Journal of Research in Science Teaching, 50(5), 561-596. doi: 10.1002/tea.21082.

Yaşar, Ş. \& Duban, N. (2009). Students' opinions regarding to the inquiry-based learning approach. Elementary Education Online, 8(2), 457-475. 